\title{
Search Activity in Google as an Indicator of Interest in the Issue of Climate Change in Cities
}

\author{
Vladimir TIKUNOV, Olga CHERESHNYA, Marina GRIBOK \\ Integrated Mapping Laboratory, Faculty of Geography, Lomonosov Moscow State University, Moscow, Russia \\ Corresponding author email: chereshnya.o@yandex.ru
}

\begin{abstract}
Growing climate threats require adequate action from the world community and individual countries. Therefore, today it is extremely important for international and national sustainable development policies to obtain reliable data on the attitude of the public in different countries to the issue of climate change. An increase in the level of awareness of the world's population regarding climate change may be used as a reliable indicator of this issue. A promising tool for studying it is the Google Trends search query counting service. The article presents a comparative analysis of interest in climate change in the cities of the world and actual climate variability in these cities. To illustrate the processes of climate change, the temperature variability ratings for the largest cities of the world and Russia for a period of 36 years between 1980 are 2016 are given. It is shown that for Russia, climate problems become more urgent with the occurrence of significant negative consequences. Climate issues are becoming more important for Russia, but the awareness of significant negative consequences is negligible. As a result, there is a low correlation between global search and temperature trends.
\end{abstract}

Keywords: climate change, cities of the world, google trends, global warming

\section{Introduction}

Reflecting the long-term warming trend since pre-industrial times, the observed global mean surface temperature for the decade $2006-2015$ was $0.87^{\circ} \mathrm{C}$ higher than the average for 1850-1900 (IPCC 2018). Growing climate threats require adequate action from the world community and individual countries. This position is reflected in United Nations conceptual documents adopted recently, for example the Paris Climate Agreement (2015), which sets the priorities for combating the climate change threat throughout the world. Among the seventeen Sustainable Development Goals adopted by the UN in 2015 for the period 2016-2030, goal 13 aims at combating climate change. One of its targets (13.3) is to "improve education, awareness-raising and human and institutional capacity on climate change mitigation, adaptation, impact reduction and early warning". An indicator of progress in solving this problem may be an increase in the interest and level of awareness of the world's population on the topic of climate change.

A large number of studies have been devoted to current climate changes (NASA 2015, Flanner 2009, Raftery et al. 2017). The fifth report of the Intergovernmental Panel on Climate Change (IPCC 2018) underlines the negative role of anthropogenic influences: human impact has been the dominant cause of climate changes since the mid-20th century, with a probability of more than $95 \%$. The global population growth rate is about 75 million, or $1.1 \%$ per year. In addition, the level of consumption is growing, which undoubtedly increases pressure on the environment. According to forecasts, over the next 30 years the world's population will increase by two billion, reaching 9.7 billion by 2050. This will undoubtedly increase the load on the environment even more, and may cause further climate changes if countermeasures are not taken.

KiG No. 33, Vol. 19, 2020 https://doi. org/10.32909/kg.19.33.4 _- 


\title{
Pretraživanja u Googleu kao pokazatelj interesa za problem klimatskih promjena u gradovima
}

\author{
Vladimir TIKUNOV, Olga ČEREŠNJA, Marina GRIBOK \\ Integrirani kartografski laboratorij, Geografski fakultet, Moskovsko državno sveučilište Lomonosova, Moskva, Rusija \\ e-adresa autora za korespondenciju: chereshnya.0@yandex.ru
}

Članak je predan na engleskom jeziku. Na hrvatski ga je preveo V. Lapaine.

The paper was submitted in English. It was translated into Croatian by V. Lapaine.

\begin{abstract}
Sažetak. Rastuće klimatske prijetnje zahtijevaju adekvatno djelovanje svjetske zajednice i pojedinih zemalja. Stoga je danas za međunarodnu i nacionalnu politiku održivog razvoja izuzetno važno dobiti pouzdane podatke 0 stavu javnosti u različitim zemljama prema pitanju klimatskih promjena na Zemlji. Porast razine svijesti stanovništva u svijetu o klimatskim promjenama može se upotrijebiti kao pouzdan pokazatelj tog problema. Obećavajuće sredstvo za njegovo proučavanje je usluga brojanja pretraživanja Google Trendsa. Članak prikazuje komparativnu analizu interesa za klimatske promjene u gradovima svijeta i stvarne klimatske varijabilnosti u gradovima. Kako bi se prikazali procesi klimatskih promjena, predstavljene su procjene temperaturne varijabilnosti za najveće gradove svijeta i Rusije tijekom 36 godina (od 1980. do 2016. godine). Pokazano je da klimatska pitanja postaju sve važnija za Rusiju, ali svijest 0 značajnim negativnim posljedicama nije uočena. U rezultatima je utvrđeno da postoji nizak odnos između globalnog pretraživanja i trendova temperature.
\end{abstract}

Ključne riječi: klimatske promjene, gradovi svijeta, trendovi prema Googleu, globalno zatopljenje

\section{Uvod}

Odražavajući dugoročni trend zagrijavanja od predindustrijskih vremena, promatrana globalna srednja temperatura površine za deset godina (2006-2015) bila je za $0,87^{\circ} \mathrm{C}$ viša od prosjeka tijekom razdoblja od 1850 . do 1900. godine (IPCC 2018). Rastuće klimatske prijetnje zahtijevaju adekvatno djelovanje svjetske zajednice i pojedinih zemalja. To se stajalište odražava u nedavno prihvaćenim konceptualnim dokumentima Ujedinjenih naroda, na primjer u Pariškom klimatskom sporazumu (2015), koji određuje prioritete u borbi protiv prijetnje klimatskim promjenama u svijetu i svim zemljama. Osim toga, među sedamnaest ciljeva održivog razvoja koje je UN usvojio u 2015. za razdoblje 2016-2020 cilj 13 je usmjeren na borbu protiv klimatskih promjena. Jedan od njegovih globalnih ciljeva (13.3) je „poboljšanje obrazovanja, podizanja svijesti i ljudskih i institucionalnih kapaciteta za ublažavanje klimatskih promjena, prilagodbu, smanjenje utjecaja i rano upozoravanje“. Pokazatelj napretka u rješavanju tog problema može biti porast interesa i razine svijesti svjetskog stanovništva o temi klimatskih promjena.

Veliki je broj studija posvećen istraživanju trenutnih klimatskih promjena (NASA 2015, Flanner 2009, Raftery i sur. 2017). Peto izvješće Međuvladinog odbora za klimatske promjene (IPCC 2018) podvlači negativnu ulogu antropogenih utjecaja: s vjerojatnošću većom od 95\% ljudski je utjecaj bio dominantan uzrok klimatskih promjena od sredine 20. stoljeća. Globalni rast stanovništva iznosi oko 75 milijuna (ili $1,1 \%$ godišnje). Uz to, raste razina potrošnje, što nesumnjivo povećava pritisak na okoliš. Prema predviđanjima, u narednih 30 godina svjetsko će se stanovništvo povećati za dvije milijarde ljudi, dosegnuvši 9,7 milijardi ljudi do 2050. godine. To će, nesumnjivo, ako se ne 
For Russia, climate issues are becoming more relevant as awareness of the significant negative consequences increases. The country is significantly affected by ongoing global processes. According to the Second Assessment Report of Roshydromet on Climate Change and its Consequences in the Territory of the Russian Federation (2014), since the mid1970s, the average surface air temperature in the country has increased at an average rate of $0.43^{\circ} \mathrm{C}$ per decade, which is more than 2.5 times higher than the global warming rate. Large-scale weather and climate anomalies have already caused enormous social, economic and environmental damage - such as the heatwave in the summer of 2010 in the European part of the country, and the River Amur flood in 2013. In the future, as a result of warming, the risks associated with economic and social objects located in the permafrost zone (which covers twothirds of the Russian territory) will increase sharply. According to World Bank experts (2009), Russia may become the most vulnerable country in Eastern Europe and Central Asia in the process of global climate change. In just a few decades, the total damage to the Russian economy from climate change caused by an increase in the number of natural disasters and disasters on its territory could reach $\$ 10$ billion. The country's territory is located in different climate zones, therefore the list of hydrometeorological phenomena which cause natural disasters is very long. Most of the country, to a greater or lesser extent, needs protection against dangerous natural phenomena. The melting of the permafrost may lead to catastrophes in the energy sector, infrastructure, and settlements. The main objects of the energy sector and productive agricultural regions are located in the zone of potential climate problems.

However, despite the numbers and reliability of research projects, the majority of the population is still skeptical and does not believe in climate change. For example, according to a European Social Survey study, only $82 \%$ of Russian citizens believe that the climate is changing (European Attitudes to Climate Change and Energy 2018).

A promising tool for studying the interest and level of awareness of climate change of the population is the Google Trends search query service. Google search activity data reflect the demand for information on any topic (Askitas 2015) around the world or in individual countries, and are currently used in various fields of science, including geography, to study the dynamics of the interest of Internet users in various processes, phenomena and objects. For example, the rate of unemployment (Simionescu and Zimmermann 2017), biodiversity (Troumbis 2017) and the potential of tourist destinations (Charalampopoulos et al. 2017) have been explored in published works using Google Trends. As noted by N. Askitas (2015, p. 4), "Internet users are a sample selected from the total population, which becomes more representative as internet penetration increases".

In recent years, a large number of scientific papers have been published that show patterns of change in the popularity of search queries on topics related to climate change. Among the topics studied are regional differences in perceptions of climate change (Hamilton and Keim 2009, Knight 2017), the impact of the media (Anderegg and Goldsmith 2014) and local weather fluctuations on interest in the topic of global warming (Deryugina 2013, Lang 2014, Sisco et al. 2017, Goebbert et al. 2012), people's concerns about climate change and the factors affecting it (Brulle et al. 2012), the level of trust in climate change information (Zaval et al. 2014), and its anthropogenic origin (Hamilton and Stampone 2013). It is believed that "climate change awareness has been related to how willingly communities adapt to climate change; thus, identifying communities' awareness could help to gain insights into communities' willingness to adopt climate change policy" (Archibald and Butt 2018). At the same time, a positive correlation was found between countries' vulnerability to climate change and public awareness of this problem (Archibald and Butt 2018).

Lang (2014), analyzing Google Trends data on the search activity of Americans on the topic of global warming, as well as data from US weather stations, found that search activity increased not only during periods of extreme summer heat and prolonged lack of precipitation, but also when there was a colder than usual winter or spring. The author suggests that during periods of prolonged cooling, people are more interested in learning about climate change. Also, cold winters may increase the search activity of skeptics who do not believe in global warming and want to confirm their views.

The impact of climate change is particularly significant in urban areas (Rosenzweig et al. 2011). This is due to the characteristics of the urban environment, such as additional warming due to the effect of the urban heat island. Therefore, an important aspect of combating climate change and its consequences is studying climate change and its perception in the urban environment.

KiG No. 33, Vol. 19, 2020, https://doi.org/10.32909/kg.19.33.4 - 
poduzmu protumjere, još više povećati opterećenje okoliša i uzrokovati daljnje klimatske promjene.

Za Rusiju klimatska pitanja postaju sve relevantnija kako raste svijest o značajnim negativnim posljedicama. Zemlja je značajno pod utjecajem globalnih procesa koji su u tijeku. Prema "Drugom izvješću o procjeni Roshidrometa o klimatskim promjenama i njegovim posljedicama na teritoriju Ruske Federacije" (2014), od sredine 1970-ih prošlog stoljeća, prosječna je temperatura površinskog zraka u zemlji porasla u prosjeku za $0,43^{\circ} \mathrm{C}$ tijekom desetljeća, što je oko 2,5 puta više od stope globalnog zagrijavanja. Vremenske i klimatske anomalije velikih razmjera već su prouzročile ogromnu društvenu, ekonomsku i ekološku štetu - poput vala vrućine u ljeto 2010. $\mathrm{u}$ europskom dijelu zemlje i poplave rijeke Amur 2013. godine. U budućnosti će se, kao posljedica zagrijavanja, rizici povezani s ekonomskim i socijalnim objektima koji se nalaze u zoni permafrosta (koji se širi na dvije trećine ruskog teritorija) naglo povećavati. Prema riječima stručnjaka Svjetske banke (2009.) u procesu globalnih klimatskih promjena Rusija može postati najugroženija zemlja istočne Europe i srednje Azije. Za nekoliko bi desetljeća ukupna šteta od klimatskih promjena za rusko gospodarstvo mogla doseći 10 milijardi dolara, što će biti uzrokovano povećanjem broja prirodnih katastrofa i katastrofa na njenom teritoriju. Teritorij države smješten je $u$ različitim klimatskim zonama pa je popis hidrometeoroloških pojava koje uzrokuju prirodne katastrofe u njegovim regijama vrlo velik. Veći dio zemlje treba zaštititi od opasnih prirodnih pojava. Rastapanje permafrosta može dovesti do katastrofa u energetskom sektoru, infrastrukturi, naseljima. U zoni potencijalnih klimatskih problema glavni su objekti energetskog sektora i proizvodne poljoprivredne regije.

No unatoč broju i pouzdanosti istraživanja, velik dio stanovništva i dalje je skeptičan i ne vjeruje u klimatske promjene. Na primjer, prema studiji Europskog socijalnog istraživanja samo $82 \%$ građana Rusije vjeruje da se klima mijenja (European Attitudes to Climate Change and Energy 2018).

Obećavajuće sredstvo za proučavanje interesa i razine svijesti stanovništva o klimatskim promjenama stanovništva je usluga pretraživanja Google Trends. Podatci o pretraživačkim aktivnostima Googlea odražavaju potražnju informacija o bilo kojoj temi (Askitas 2015) širom svijeta ili pojedinih zemalja i trenutno se koriste $u$ raznim poljima znanosti, uključujući geografiju, kako bi se proučila dinamika interesa internetskih korisnika za razne procese, pojave i objekte. Tako su, primjerice, objavljeni su članci u kojima se istražuje stopa nezaposlenosti (Simionescu i Zimmermann 2017), bioraznolikost (Troumbis 2017) i potencijal turističkih odredišta
(Charalampopoulos i sur. 2017) s pomoću Google Trendsa. Kao što je napomenuo N. Askitas (2015, str. 4), "Korisnici interneta su uzorak odabranih iz ukupnog broja stanovnika koji postaje sve reprezentativniji kako se povećava prodor interneta".

Posljednjih je godina objavljen veći broj znanstvenih radova koji prikazuju obrasce promjene u popularnosti upita za pretraživanje o temama koje se odnose na klimatske promjene. Proučavaju se regionalne razlike u percepciji klimatskih promjena (Hamilton i Keim 2009, Knight 2017), utjecaj medija (Anderegg i Goldsmith 2014) i lokalne vremenske fluktuacije na interes za temu globalnog zagrijavanja (Deryugina 2013, Lang 2014, Sisco i sur. 2017, Goebbert i sur. 2012), zabrinutost ljudi o klimatskim promjenama i čimbenicima koji utječu na nju (Brulle i sur. 2012) i, zapravo, razina povjerenja $\mathrm{u}$ informacije o klimatskim promjenama (Zaval i sur. 2014) i njegovo antropogeno podrijetlo (Hamilton i Stampone 2013). Vjeruje se da je „svijest o klimatskim promjenama povezana s načinom na koji se voljne zajednice prilagođavaju klimatskim promjenama; na taj bi način prepoznavanje svijesti zajednica moglo pomoći uvidu u spremnost zajednica da usvoje politiku klimatskih promjena" (Archibald i Butt 2018). Istovremeno, pronađena je pozitivna povezanost između ranjivosti zemalja na klimatske promjene i svijesti javnosti o tom problemu (Archibald i Butt 2018).

Analizirajući podatke Google Trendsa o pretraživačkoj aktivnosti Amerikanaca na temu globalnog zagrijavanja, kao i podatke meteoroloških stanica u SAD-u, Lang (2014) je utvrdio da se pretraživačka aktivnost povećava ne samo tijekom razdoblja ekstremnih ljetnih vrućina i dugotrajnog nedostatka padalina, nego i tamo gdje je hladnije od uobičajene temperature zimi ili $u$ proljeće. Autor sugerira da su ljudi tijekom razdoblja dužeg hlađenja više zainteresirani za učenje o klimatskim promjenama. Hladne zime mogu također povećati pretraživačku aktivnost skeptika koji ne vjeruju u globalno zagrijavanje i žele potvrditi svoja stajališta.

Utjecaj klimatskih promjena može biti posebno značajan u urbanim područjima (Rosenzweig i sur. 2011). To je zbog karakteristika urbanog okoliša, poput dodatnog zagrijavanja pod utjecajem urbanog otoka topline. Stoga je važan aspekt borbe protiv klimatskih promjena i njegovih posljedica proučavanje klimatskih promjena i njegova percepcija u urbanom okruženju.

\section{Materijali i metode}

Zagrijavanje veće od svjetskog godišnjeg prosjeka primijećeno je u mnogim kopnenim regijama i 


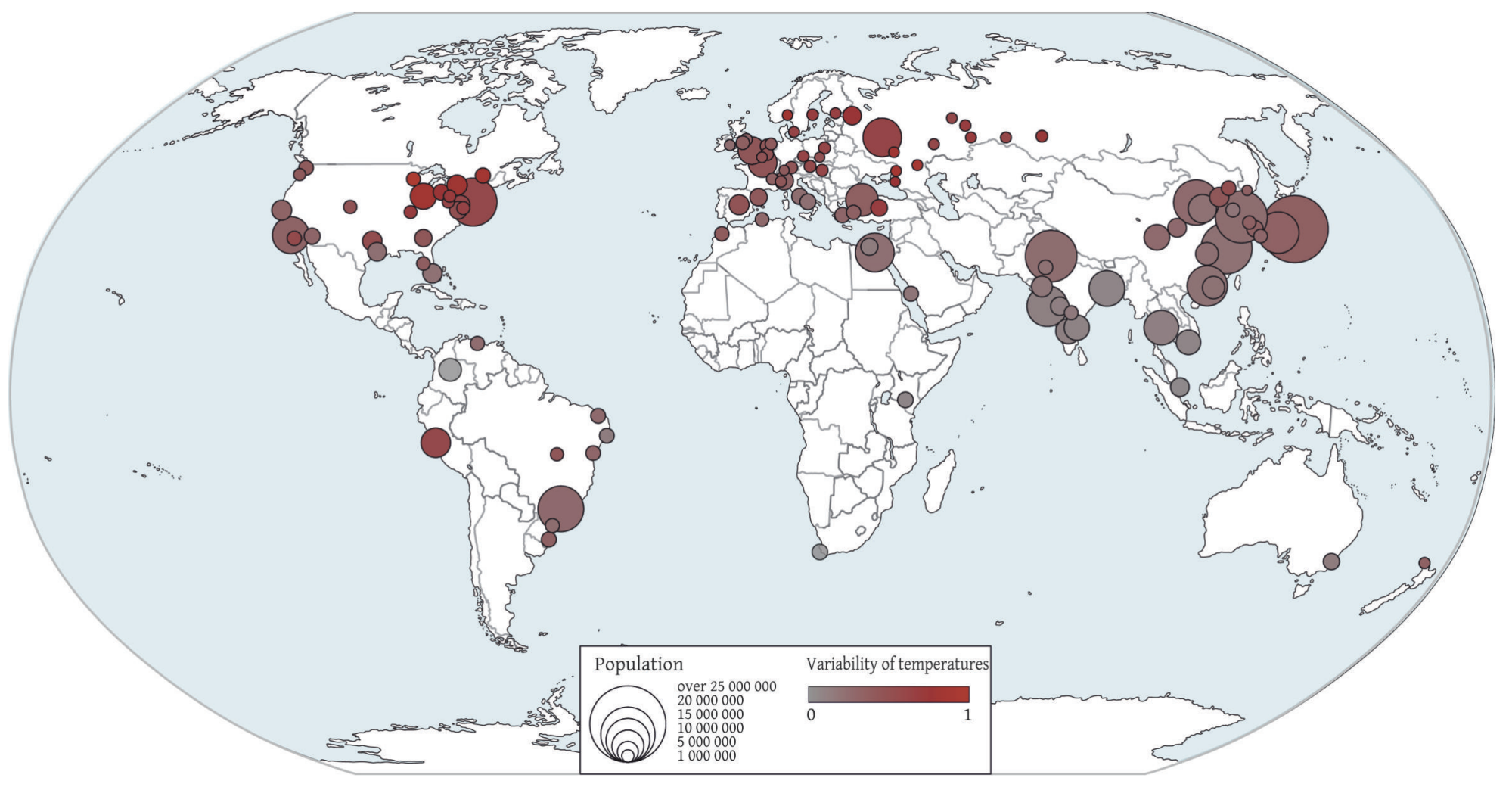

Fig. 1 Fluctuations in average annual temperatures from year to year.

Slika 1. Kolebanja srednje godišnje temperature iz godine u godinu.

\section{Materials and Methods}

Warming greater than the annual global average is experienced in many land regions and seasons, and is as much as two or three times higher in the Arctic (IPCC 2018). In order to measure temperature variations in cities which cause citizens anxiety, the authors developed temperature variability ratings for cities throughout the world and assessed them for the period 1980 to 2016. The first rating showed fluctuations in average annual temperatures from year to year, and the second a series of anomalies relative to the average temperature over the entire period. An evaluative algorithm (Tikunov 1997) was used to calculate the variability rankings. It included standardization of the initial indicator system according to the formula:

$$
\hat{x}_{i j}=\frac{\left|x_{i j}-{ }^{0} x_{j}\right|}{\left|\max / \min x_{j}-{ }^{0} x_{j}\right|}, i=1,2,3, \ldots, n ; j=1,2,3, \ldots, m ;
$$

where ${ }^{0} x$ represented the theoretically worst values (in this study, zero for all three indicators - one can also take the worst values for each indicator), $\max / \min x$ represented the greatest deviation from ${ }^{0} x$ values, $n$ was the number of territorial units, and $m$ was the number of indicators used for calculations. All the initial indicators were given equal weight. The purpose of this standardization was to translate the indicator into a deviation from the specified best or worst value.

Often, summation or averaging is used for aggregation in an index. But by averaging several initial indicators, we inevitably reduce all information to the average level. This approach is unreliable for evaluation. So a method based on calculating the Euclidean distances to the worst unit (d) was used. This allows the effect of individual coordinates, with anomalously large differences because they are squared, to be emphasized. The application of this measure required processing the information array according to the method of principal components, with the aim of orthogonalisation and 'convolution' of the system of indicators (Tikunov 1997).

For the convenience of further analysis, the obtained values of $(d)$ were additionally standardized according to the following formula:

$$
\hat{d}_{i}=\frac{d_{i}-{ }_{\text {min }} d}{D \text { max } d-{ }_{\text {min }} d}, i=1,2,3, \ldots, n \text {. }
$$

KiG No. 33, Vol. 19, 2020, https://doi.org/10.32909/kg.19.33.4 - - 
sezonama uključujući dva do tri puta veće na Arktiku (IPCC 2018). Za mjerenje stupnja promjene temperature $\mathrm{u}$ gradovima koji mogu izazvati anksioznost građana autori su razvili ocjene varijabilnosti temperature za svjetske gradove i dali procjenu za razdoblje od 1980. do 2016. Prva ocjena pokazuje fluktuacije prosječnih godišnjih temperatura iz godine $u$ godinu, a druga niz anomalija u odnosu na prosječnu temperaturu tijekom cijelog razdoblja. Evaluacijski algoritam (Tikunov 1997) korišten za proračun ljestvice varijabilnosti sadrži normalizaciju sustava početnih pokazatelja po formuli:

$$
\hat{x}_{i j}=\frac{\left|x_{i j}-{ }^{0} x_{j}\right|}{\left|\max / \min x_{j}-{ }^{0} x_{j}\right|}, i=1,2,3, \ldots, n ; j=1,2,3, \ldots, m ;
$$

gdje ${ }^{0} x$ predstavlja teorijski moguće najgore vrijednosti, u ovoj studiji nula za sva tri pokazatelja (mogu se upotrijebiti i najgore vrijednosti za svaki pokazatelj); ${ }_{\max / \min } x$ - ekstremne vrijednosti među svim vrijednostima ${ }^{0} x ; n$ - broj teritorijalnih jedinica; $m$ - broj pokazatelja upotrijebljenih za računanja. Svim je početnim pokazateljima dana jednaka težina. Svrha je normalizacije pomicanje pokazatelja na odstupanje od specificirane najbolje ili najlošije vrijednosti.

Često se zbrajanje ili prosjek koristi za združivanje $u$ jedan indeks. No usrednjavanjem nekoliko početnih pokazatelja neminovno će reducirati sve informacije na prosječnu razinu. Takav pristup nije pouzdan za procjenu. Zbog toga je upotrijebljena metoda utemeljena na euklidskim udaljenostima $u$ odnosu na najlošiju jedinicu (d). To omogućava isticanje učinka pojedinih koordinata s anomalijski velikim razlikama jer su one kvadrirane. Primjena te mjere zahtijevala je obradu informacijskog niza metodom glavnih komponenti s ciljem ortogonalizacije i konvolucije sustava pokazatelja (Tikunov 1997).

Dobivene vrijednosti (d) su za daljnju analizu dodatno normalizirane s pomoću formule:

$$
\hat{d}_{i}=\frac{d_{i}-{ }_{\text {min }} d}{D \text { max } d-_{\text {min }} d}, i=1,2,3, \ldots, n \text {. }
$$

Vrijednosti $\hat{d}_{i}$ variraju od 0 do 1,0 odgovara najlošijoj sveobuhvatnoj procjeni, a 1 najboljoj.

Dobiveni rezultati prikazani su na kartama (slike 1 i 2) i u tablici 1.

Procjena pokazuje varijabilnost temperatura $u$ različitim regijama. Najjača su kolebanja temperature iz godine $u$ godinu zabilježena $u$ gradovima
Središnje Rusije, Uralske regije i New Yorka. I najveća varijabilnost $u$ odnosu na prosječnu temperaturu tijekom čitavog razdoblja u srednjoj i sjevernoj Europi te crnomorskoj regiji.

$\mathrm{Za}$ analizu interesa građana upotrijebljeni su sljedeći podatci: dinamika i distribucija Google upita za pretraživanje u gradovima svijeta na teme "Globalno zagrijavanje“ i „Klimatske promjene“, kao i dugoročne vrijednosti kolebanja prosječnih godišnjih temperatura zraka u gradovima svijeta.

Ako unesete bilo koji upit u traku za pretraživanje, usluga stvara izvješće o pretraživačkoj aktivnosti Googlea za taj upit i vizualizira sljedeće slike i podatke: 1) grafikon dinamike popularnosti tog upita u svijetu ili bilo kojoj odabranoj zemlji za odabrano razdoblje, od 2004. godine; 2) kartu i popis gradova ili zemalja ili regija odabrane zemlje s najvišom razinom popularnosti ovog upita. Popularnost upita u Google Trendsu je relativna vrijednost koja karakterizira udio ovog upita među svim upitima pretraživanja za odabrano razdoblje i ne ovisi o populaciji. Svi su pokazatelji normalizirani: maksimalna razina popularnosti pitanja uzima se kao $100 \%$, a preostale se vrijednosti pretvaraju u postotke $u$ odnosu na to. Dakle, dobivena vrijednost popularnosti ne ovisi o broju stanovnika i ukupnom broju pitanja, već samo o njihovom udjelu u ukupnom protoku pitanja.

Neka pitanja Google Trends prepoznaje kao "teme”. Prema opisu podrške za uslugu (https://support.google.com/trends/) to su grupe tematski sličnih upita na svim jezicima svijeta. Građa za ovu studiju bila je statistika Google Trendsa na upitima pretraživanja na teme "Globalno zagrijavanje" i "Klimatske promjene" koje potječu iz svih zemalja svijeta u razdoblju od 2004. do 2016. godine.

Graf usporedbe dinamike popularnosti dviju tema pretraživanja prikazan je na slici 3.

Maksimalni je interes za temu globalnog zagrijavanja zabilježen u ožujku 2007. Možda je to zbog premijere britanskog dokumentarnog filma The Great Global Warming Swindle koji je izazvao poplavu kritika i veliko negodovanje javnosti širom svijeta (Jones i sur. 2007). Od tada postupno opada zanimanje za taj fenomen. Što se tiče teme klimatskih promjena, za razinu zanimanja za nju karakteristična je relativna stalnost s lokalnim maksimumom u prosincu 2009. Vjeruje se da je povezan $s$ konferencijom Ujedinjenih naroda o klimatskim promjenama koja je održana u Kopenhagenu u Danskoj 7.-18. prosinca 2009. Konferencija je obuhvatila i 5. sastanak stranaka Kjotskog protokola i široko 


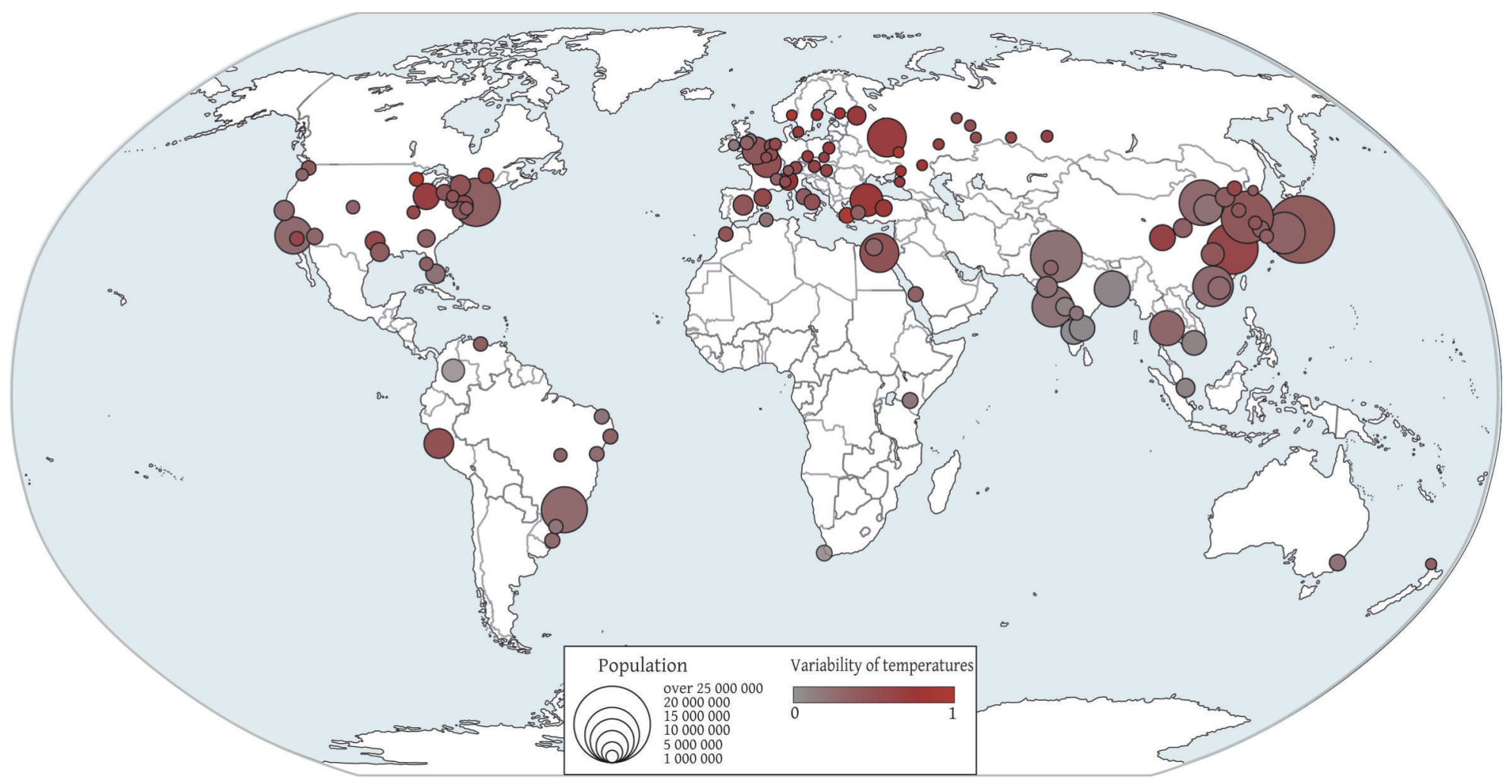

Slika 2. Kolebanja u odnosu na srednju temperaturu tijekom cijelog razdoblja.

Fig. 2 Fluctuations relative to the average temperature over the entire period.

The value of $\hat{d}_{i}$ varied from 0 to 1 , in which 0 corresponded to the worst comprehensive evaluation and 1 to the best.

The results obtained are presented on maps (Figues 1 and 2) and in the table in the appendix.

The evaluation shows the variability of temperatures in different regions. The greatest temperature fluctuations from year to year were recorded in the cities of Central Russia, the Ural region, and New York. The greatest variability relative to the average temperature over the entire period was recorded in Central and Northern Europe, in the Black Sea region.

The following data was used to analyze the interest of citizens: the dynamics and distribution of Google search queries in cities throughout the world on the topics of global warming and climate change, and the long-term values of fluctuations in average annual air temperatures in those cities.

If you enter any query in the search bar, the service creates a report on Google search activity for this query and visualizes the following images and data: 1) a graph of the dynamics of the popularity of this query in the world or any selected country for a selected period of time, since 2004, and 2) a map and a list of cities, countries, or regions of the selected country with the highest level of popularity for this query. The popularity of a query in Google Trends is a relative value that characterizes the proportion occupied by this query among all search queries for the selected period, and does not depend on the population. All indicators are standardized: the maximum level of popularity of the request is taken as $100 \%$, and the remaining values are converted into percentages relative to this benchmark. Thus, the resulting popularity value does not depend on the population or total number of requests, but only on their proportion in the total number of requests received.

Some queries are recognized by Google Trends as 'topics'. According to the service support description (https://support.google.com/trends/), these are groups of thematically similar queries in all languages of the world. This study was based on Google Trends statistics on search queries on the topics of 'global warming' and 'climate change', originating from all countries of the world between 2004 and 2016.

A comparative graph of the dynamics of the popularity of the two search topics is presented in Figure 3.

KiG No. 33, Vol. 19, 2020, https://doi.org/10.32909/kg.19.33.4 - - 
Tablica 1. Kolebanja temperature i rezultati pretraživanja po gradovima širom svijeta. Table 1 Temperature fluctuations and search queries from cities around the world.

\begin{tabular}{|c|c|c|c|c|c|c|}
\hline & $\begin{array}{l}\text { Fluctuations } \\
\text { relative to the } \\
\text { average } \\
\text { temperature over } \\
\text { the entire period } \\
\text { (from 0 to 1) } \\
\text { Kolebanja u } \\
\text { odnosu na } \\
\text { prosječnu } \\
\text { temperaturu u } \\
\text { cijelom razdoblju } \\
\text { (od 0 do 1) }\end{array}$ & $\begin{array}{l}\text { Place in the rating } \\
\text { of fluctuations } \\
\text { relative to the } \\
\text { average } \\
\text { temperature over } \\
\text { the entire period } \\
\text { Mjesto u ocjeni } \\
\text { kolebanja u } \\
\text { odnosu na } \\
\text { prosječnu } \\
\text { temperaturu u } \\
\text { čitavom razdoblju }\end{array}$ & $\begin{array}{l}\text { Fluctuations in } \\
\text { average annual } \\
\text { temperatures } \\
\text { from year to year } \\
\text { (from } 0 \text { to } 1 \text { ) } \\
\text { Kolebanje } \\
\text { prosječnih } \\
\text { godišnjih } \\
\text { temperatura iz } \\
\text { godine u godinu } \\
\text { (od } 0 \text { do } 1 \text { ) }\end{array}$ & $\begin{array}{c}\text { Place in the } \\
\text { rating of } \\
\text { fluctuations in } \\
\text { average annual } \\
\text { temperatures } \\
\text { from year to year } \\
\text { Mjesto u ocjeni } \\
\text { kolebanja } \\
\text { prosječnih } \\
\text { godišnjih } \\
\text { temperatura iz } \\
\text { godine u godinu }\end{array}$ & $\begin{array}{l}\text { Popularity } \\
\text { index of the } \\
\text { request on } \\
\text { the topic of } \\
\text { climate } \\
\text { change } \\
\text { Indeks } \\
\text { popularnosti } \\
\text { pitanja o } \\
\text { klimatskim } \\
\text { promjenama }\end{array}$ & $\begin{array}{l}\text { Popularity } \\
\text { index of the } \\
\text { request on the } \\
\text { topic of global } \\
\text { warming } \\
\text { Indeks } \\
\text { popularnosti } \\
\text { pitanja o } \\
\text { globalnom } \\
\text { zagrijavanju }\end{array}$ \\
\hline Ankara & $0.18 / 0,18$ & 108 & $0.18 / 0,18$ & 99 & & 31 \\
\hline Bangalore & $0.04 / 0,04$ & 1 & $0.06 / 0,06$ & 9 & & 35 \\
\hline Bangkok & $0.10 / 0,10$ & 32 & $0.06 / 0,06$ & 10 & & 78 \\
\hline Bogota & $0.06 / 0,06$ & 6 & $0.04 / 0,04$ & 1 & 37 & 57 \\
\hline Caracas & $0.11 / 0,11$ & 49 & $0.09 / 0,09$ & 34 & & 71 \\
\hline $\begin{array}{l}\text { Chennai } \\
\text { (Madras) }\end{array}$ & $0.05 / 0,05$ & 2 & $0.06 / 0,06$ & 7 & & 43 \\
\hline Chicago & $0.17 / 0,17$ & 100 & $0.21 / 0,21$ & 112 & 18 & 27 \\
\hline Delhi & $0.08 / 0,08$ & 16 & $0.09 / 0,09$ & 31 & 25 & 65 \\
\hline Hyderabad & $0.07 / 0,07$ & 10 & $0.07 / 0,07$ & 15 & & 45 \\
\hline Istanbul & $0.18 / 0,18$ & 107 & $0.11 / 0,11$ & 59 & & 22 \\
\hline London & $0.12 / 0,12$ & 65 & $0.13 / 0,13$ & 70 & 31 & 25 \\
\hline Los Angeles & $0.09 / 0,09$ & 26 & $0.10 / 0,10$ & 45 & 25 & 33 \\
\hline Madrid & $0.12 / 0,12$ & 64 & $0.13 / 0,13$ & 77 & 37 & 14 \\
\hline $\begin{array}{l}\text { Mumbai } \\
\text { (Bombay) }\end{array}$ & $0.08 / 0,08$ & 13 & $0.06 / 0,06$ & 8 & & 55 \\
\hline Nairobi & $0.07 / 0,07$ & 11 & $0.05 / 0,05$ & 4 & 81 & \\
\hline New York & $0.11 / 0,11$ & 48 & $0.16 / 0,16$ & 86 & 31 & 31 \\
\hline Paris & $0.13 / 0,13$ & 72 & $0.13 / 0,13$ & 74 & 12 & \\
\hline Pune & $0.06 / 0,06$ & 4 & $0.06 / 0,06$ & 11 & & 37 \\
\hline San Francisco & $0.09 / 0,09$ & 27 & $0.10 / 0,10$ & 46 & 31 & \\
\hline Sao Paulo & $0.09 / 0,09$ & 23 & $0.09 / 0,09$ & 39 & & 45 \\
\hline Singapore & $0.06 / 0,06$ & 7 & $0.05 / 0,05$ & 3 & 31 & 35 \\
\hline Toronto & $0.13 / 0,13$ & 69 & $0.20 / 0,20$ & 109 & 50 & 39 \\
\hline Washington DC & $0.11 / 0,11$ & 57 & $0,14 / 0,14$ & 80 & 75 & \\
\hline
\end{tabular}

je medijski pokrivena u cijelom svijetu. Od sredine 2015. obje su linije trenda vrlo blizu jedna drugoj.

Teritorijalne razlike $u$ raspodjeli popularnosti tih dviju tema u odnosu na gradove prikazane su na slici 4 . Pojačano zanimanje za temu globalnog zagrijavanja može se primijetiti u gradovima takvih regija kao što su Srednja Amerika i južna i jugoistočna Azija. Najveća je pretraživačka aktivnost na tu temu zabilježena u Mexico Cityju, Bangkoku, Caracasu, New Delhiju i Bogoti.
Pojačana je pretraživačka aktivnost na temu „Klimatske promjene“ primijećena u različitim regijama svijeta: jugoistočnoj Aziji, zapadnoj Europi, sjeveroistoku Sjedinjenih Država itd. Među glavnim gradovima s povećanom pretraživačkom aktivnošću na tu temu nalaze se gradovi u zemljama u razvoju (Nairobi, Mexico City, Bogota) i razvijeni (Washington, Sydney, Melbourne, Toronto, Madrid). 


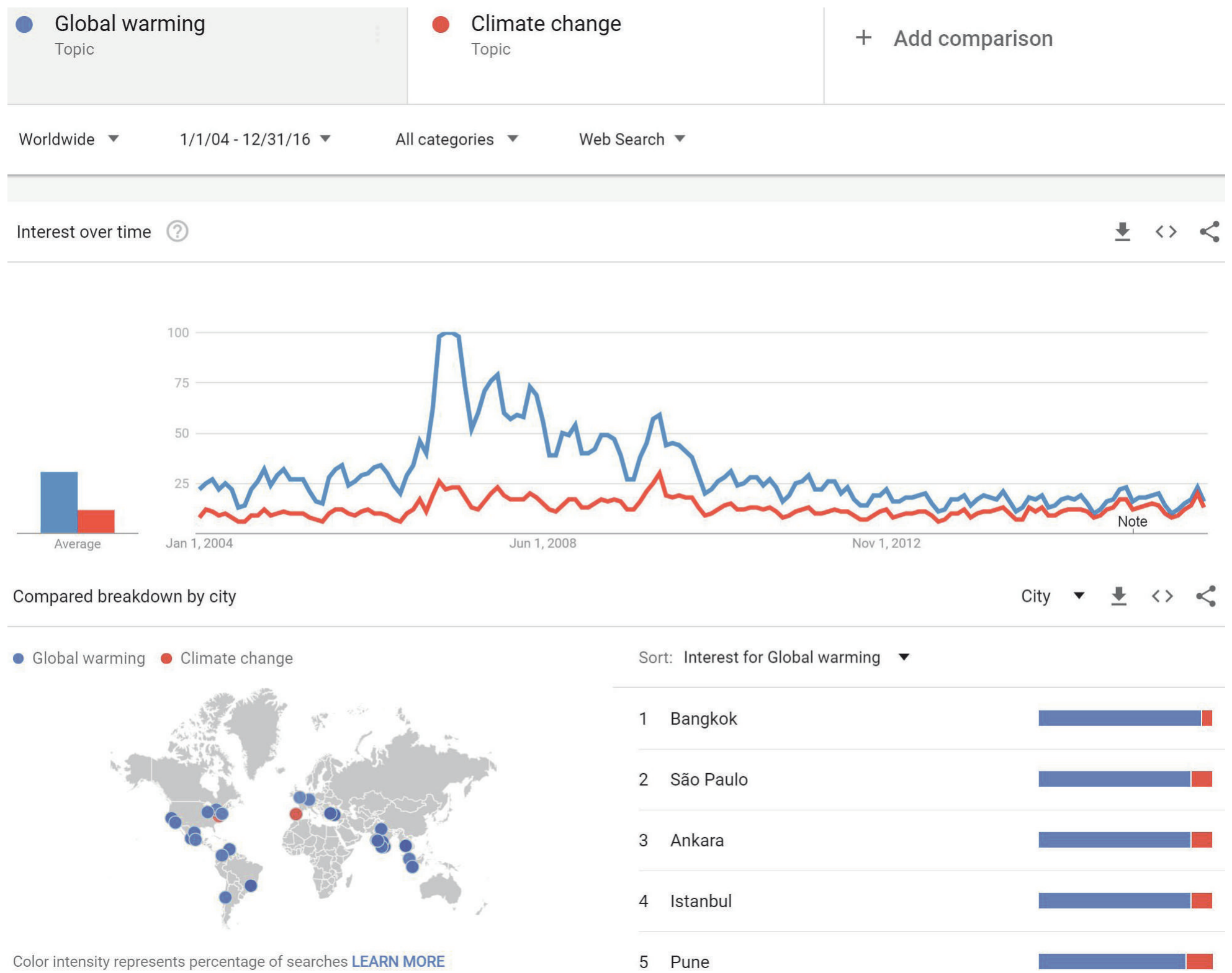

Fig. 3 Dynamics of the popularity of Google queries on the topics of 'global warming' and 'climate change': 2004-2016.

Slika 3. Dinamika popularnosti Google upita na teme „Globalno zagrijavanje“ i „Klimatske promjene“ u razdoblju 2004-2016. 

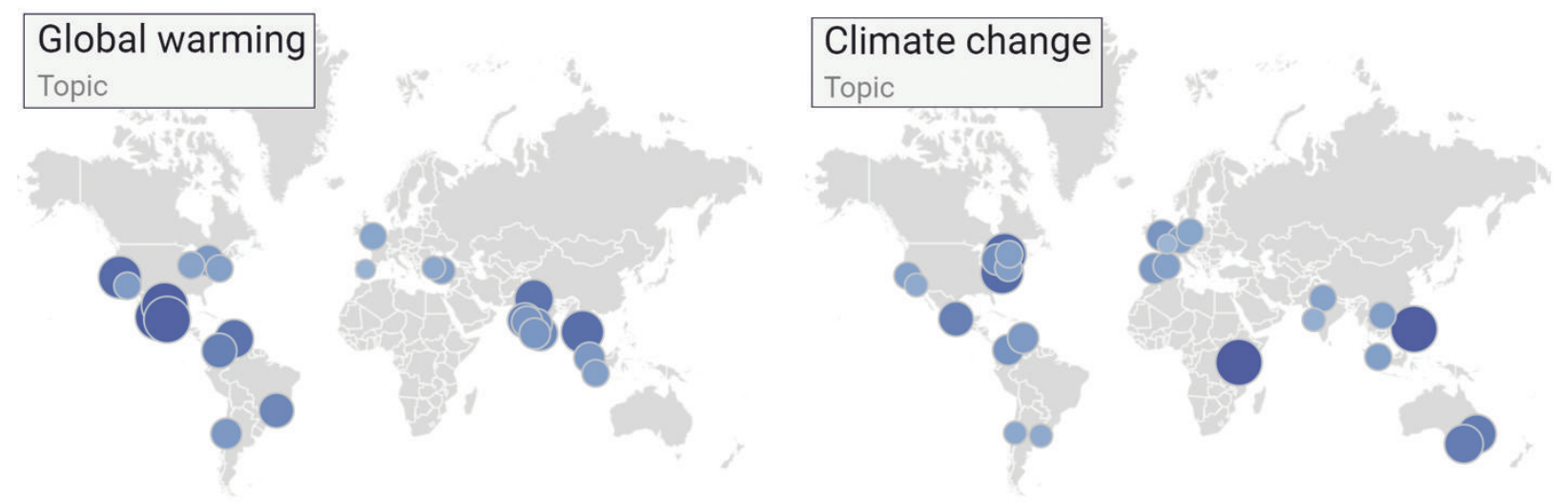

Slika 4. Gradovi s visokom razinom aktivnosti pretraživanja Googlea na temu „Globalno zagrijavanje“ i „Klimatske promjene“ u razdoblju 2004-2016.

Fig. 4 Cities with a high level of Google search activity on 'Global warming' and 'Climate change' in the period 2004-2016.

\section{Rezultati i rasprava}

Kao rezultat, analize podataka o pretraživačkoj aktivnosti korisnika i kolebanja prosječnih godišnjih temperatura u gradovima dobiveni su popisi gradova u kojima: 1) postoji povećan interes korisnika za teme klimatskih promjena i globalnog zagrijavanja; 2) postoje izražena veća kolebanja temperature zraka iz godine u godinu od 1980. i povećana kolebanja od srednjih višegodišnjih temperaturnih vrijednosti (tablica 1). Crvena boja označava velika kolebanja temperature i broja upita, a zelena boja stabilniju temperaturu i visok broj upita.

Usporedbom tih popisa ustanovljeno je da su pogodci istog grada na oba popisa vrlo rijetki, tj. postoji nizak odnos između globalnih trendova pretraživanja i temperature. Naprotiv, otkrivena je obrnuta veza. Među gradovima u kojima nije primijećena povećana temperaturna varijabilnost bilo je više točaka povećanog interesa za klimatske promjene nego $u$ onim gradovima $u$ kojima su indeksi temperaturne varijabilnosti veći. Na primjer, Bogota ima stabilne ocjene temperature i visoke upite na temu "Globalno zagrijavanje". Chicago, naprotiv, pokazuje velika kolebanja temperature i nisko zanimanje korisnika. Ruski gradovi, usprkos visokim oscilacijama temperature, nisu na popisu gradova s povećanim interesom korisnika za klimatske promjene i globalno zagrijavanje. To je jedan od najneočekivanijih rezultata jer je ruska arktička regija jedna od najosjetljivijih na globalno zagrijavanje i njezine manifestacije trebaju biti vidljive stanovništvu. Konkretno, permafrost se topi, što dovodi do uništenja kapitalnih zgrada i infrastrukture (Turetsky i sur. 2019).
Ti podatci potvrđuju pretpostavku da zanimanje za temu klimatskih promjena ne ovisi o stvarnim promatranjima stanovnika, već o drugim čimbenicima. Na primjer, preliminarna zapažanja pokazuju da su svijest građana, obrazovni programi, vladini programi i aktivno izvještavanje o medijima važni za generiranje interesa javnosti za problem. To se objašnjava činjenicom da su anksioznost $i$ interes korisnika češće uzrokovani događajima koji su široko pokriveni u medijima širom svijeta, a ne višegodišnjim i dugotrajnim promjenama koje je teško otkriti bez višegodišnjih mjerenja. Zadaća akademske zajednice i vlade je privući pažnju i objasniti klimatske promjene koje se događaju. To će pomoći u postizanju izvanrednih rezultata zaštite okoliša temeljenih na konsenzusu društva u vezi s ciljevima ekološke i energetske politike i oblikovanjem učinkovitih ekonomskih i pravnih sredstava potpore. To postaje izvodljivije zbog provođenja ciljeva održivog razvoja u nacionalnoj politici.

Uz to, treba spomenuti da podatci sintetizirani iz Google Trendsa mogu biti nepouzdani u zemljama koje postavljaju ograničenja na internetske tražilice poput Googlea (npr. Kina). Međutim, upotreba podataka Google Trendsa za istraživanje svijesti o klimatskim promjenama može pružiti prednosti u odnosu na tradicionalnije metode (kao što su godišnje ankete) koje mogu biti ograničene svojom učestalošću i troškovima.

\section{Financiranje}

Ovaj je rad financijski podržala Ruska zaklada za znanost (Russian Science Foundation (RSF, Projekti No. 20-47-01001). 
Maximum interest in the topic of global warming was observed in March 2007. Perhaps this was due to the showing of a British documentary, The Great Global Warming Swindle, which caused a flood of criticism and public outcry around the world (Jones et al. 2007). Since then, there has been a gradual decline in interest in this phenomenon. Regarding the topic of climate change, the level of interest in it has been relatively constant, with a local maximum in December 2009, perhaps linked to the United Nations Climate Change Conference which was held in Copenhagen, Denmark, 7-18 December 2009. The conference included the 5th Meeting of the Parties to the Kyoto Protocol and was widely covered in media around the world. Since the mid-2015, both trend lines have remained close to each other.

Territorial differences in the distribution of the popularity of these two topics by city are presented in Figure 4. Increased interest in the topic of global warming has been noted in cities in Central America and South and South-East Asia. The highest levels of search activity on this topic have been recorded in Mexico City, Bangkok, Caracas, New Delhi, and Bogota.

On the climate change, increased search activity was been observed in Southeast Asia, Western Europe, the northeastern United States, and other areas. Among major cities with increased search activity on this topic are some in developing countries (Nairobi, Mexico City and Bogota), and developed countries (Washington, Sydney, Melbourne, Toronto and Madrid).

\section{Results and Discussion}

As a result of the analysis of data on search activity by users and fluctuations in average annual temperatures in cities, lists of cities were obtained where 1) there has been increased user interest in the topics of climate change and global warming, and 2) there have been marked higher air temperature fluctuations from year to year since 1980, and increased fluctuations from the mean multiyear temperature values (Table 1). Red marks high fluctuations in temperature and the number of queries, and green marks more stable temperatures and a high number of queries.

As a result of comparing these lists, it was found that hits of the same city on both lists are very rare, i.e. there is a low correlation between global searches and temperature trends. In fact, an inverse correlation was revealed. Among the cities where no increased temperature variability was observed, there were more points of increased interest in climate change than in cities where the indices of temperature variability were higher. For example, Bogota has both stable temperature ratings and high queries on the topic of global warming. Chicago, on the other hand, shows high fluctuations in temperature and low user interest. Russian cities, in spite of high fluctuations in temperature, did not feature on the list of cities with heightened user interest in climate change and global warming. This was one of the most unexpected results because the Russian Arctic region is one of the most sensitive to global warming and its manifestations should be visible to the population. In particular, the permafrost is melting, leading to the destruction of capital buildings and infrastructure (Turetsky et al. 2019).

The data confirm the notion that interest in the topic of climate change does not depend on actual observations by residents, but on other factors. For example, preliminary observations show that citizen awareness, educational programs, government programs, and active media coverage are important in order to generate public interest in the problem. This is explained by the fact that anxiety and user interest are more often caused by events that are widely covered in the media around the world, rather than by perennial, long-lasting changes that are difficult to detect without multi-year measurements. The task of the academic community and government is to attract attention and explain the climate changes taking place. This will help to achieve outstanding environmental results based on consensus regarding the goals of environmental and energy policy and the formation of effective economic and legal support tools. The task is becoming more feasible, due to the implementation of sustainable development goals in national policies.

Additionally, we should mention that information synthesized from Google Trends may be unreliable for countries which place restrictions on internet search engines such as Google (e.g. China). However, using Google Trends data to survey climate change awareness may provide advantages over more traditional methods that may be limited in terms of frequency and costs (for example, yearly polls).

\section{Funding}

This work was financially supported by the Russian Science Foundation (RSF) (Projects No. 20-4701001)

KiG No. 33, Vol. 19, 2020, https://doi.org/10.32909/kg.19.33.4 - - 


\section{References / Literatura}

Adapting to Climate Change in Europe and Central Asia. Washington DC, The World Bank, 2009

Anderegg WRL, Goldsmith GR (2014) Public interest in climate change over the past decade and the effects of the 'climategate' media event, Environmental Research Letters, V. 9, No 5 (054005)

Archibald CL, Butt N (2018) Using Google search data to inform global climate change adaptation policy. Climatic Change, V. 150, issue 3-4, p. 447-456, doi: 10.1007/s10584-018-2289-9

Askitas N (2015) Google search activity data and breaking trends. IZA World of Labor, Institute for the Study of Labor (IZA), 206, 1-10

Brulle RJ, Carmichael J, Jenkins JC (2012) Shifting public opinion on climate change: an empirical assessment of factors influencing concern over climate change in the U.S., 2002-2010. Climatic Change 114 (2). p. 169-188, doi: 10.1007/s10584-012-0403-y

Charalampopoulos I, Nastos P, Didaskalou E (2017) Human Thermal Conditions and North Europeans' Web Searching Behavior (Google Trends) on Mediterranean Touristic Destinations, Urban Science, 1, 4, (8)

Deryugina T (2013) How do people update? The effects of local weather fluctuations on beliefs about global warming. Clim. Chang. 118, 1-20

European Attitudes to Climate Change and Energy (2018) ESS Topline Results Series, issue 9. URL http://www.europeansocialsurvey.org/docs/findings/ESS8_toplines_issue_9_climatechange.pdf

Flanner MG (2009) Integrating anthropogenic heat flux with global climate models, Geophys. Res. Lett., 36, L02801, doi:10.1029/2008GL036465

Goebbert K, Jenkins-Smith HC, Klockow K, Nowlin MC, Silva CL (2012) Weather, climate, and worldviews: the sources and consequences of public perceptions of climate change in local weather patterns. Weather Climate Soc 4(2), 132-144

Hamilton L, Stampone M (2013) Blowin' in the wind: short-term weather and belief in anthropogenic climate change. Weather Climate Soc 5 (2), 112-119

Hamilton LC, Keim BD (2009) Regional variation in perceptions about climate change. Int. J. Climatol. 29, 2348-2352

IPCC (2018) Summary for Policymakers. In: Global Warming of $1.5^{\circ} \mathrm{C}$. An IPCC Special Report on the impacts of global warming of $1.5^{\circ} \mathrm{C}$ above pre-industrial levels and related global greenhouse gas emission pathways, in the context of strengthening the global response to the threat of climate change, sustainable development, and efforts to eradicate poverty [Masson-Delmotte V, P Zhai, H-O Pörtner, D Roberts, J Skea, PR Shukla, A Pirani, W Moufouma-Okia, C Péan, R Pidcock, S Connors, JBR Matthews, Y Chen, X Zhou, MI Gomis, E Lonnoy, T Maycock, M Tignor, T Waterfield (eds.)]. World Meteorological Organization, Geneva, Switzerland, 32 pp

Jones D, Watkins A, Braganza K, Coughlan M (2007) “The Great Global Warming Swindle”: a critique. Bulletin of the Australian Meteorological and Oceanographic Society, 20 (3), 63-72

Knight KW (2017) Public awareness and perception of climate change: a quantitative cross-national study. Environ Sociol 2:101-113, doi: 10.1080/23251042.2015.1128055

Lang C (2014) Do weather fluctuations cause people to seek information about climate change? Climatic change, 125 (3-4), 291-303

NOAA Analyses Reveal Record-Shattering Global Warm Temperatures in 2015 (2016) NASA

Paris Climate Agreement (2015) Conference of the Parties. Twenty-first session. Paris, November 30 - December 11, 2015. United Nations Framework Convention on Climate Change

Raftery AE, Zimmer A, Frierson DM, Startz R, Liu P (2017) Less than $2{ }^{\circ} \mathrm{C}$ warming by 2100 unlikely. Nature Climate Change 7 , 637-641, doi:10.1038/nclimate3352

Rosenzweig C, Solecki WD, Hammer SA, Mehrotra S (2011) Climate Change and Cities: First Assessment Report of the Urban Climate Change Research Network, Cambridge Univ. Press

Simionescu M, Zimmermann KF (2017) Big Data and Unemployment Analysis. GLO Discussion Paper Series 81, Global Labor Organization (GLO)

Sisco MR, Bosetti V, Weber EU (2017) When do extreme weather events generate attention to climate change? Clim. Chang. 143:227-241, https://doi.org/10.1007/s10584-017-1984-2

The second assessment report of Rosgyromet on climate change and their consequences on the territory of the Russian Federation. General summary (2014) Moscow, Roshydromet

Tikunov VS (1997) Classifications in geography: renaissance or fading? (The experience of formal classifications). Moscow, Smolensk, Publishing House of the Smolensk University

Troumbis AY (2017) Google Trends and cycles of public interest in biodiversity: the animal spirits effect, Biodiversity and Conservation, V. 26, 14, (3421)

Turetsky MR, Abbott BW, Jones MC, Walter Anthony K, Olefeldt D, Schuur EAG, Koven C, McGuire AD, Grosse G, Kuhry P, Hugelius G, Lawrence DM, Gibson C, Sannel ABK (2019) Permafrost collapse is accelerating carbon release. Nature. May, 569 (7754):32-34, doi: 10.1038/d41586-019-01313-4

Zaval L, Keenan E, Johnson E, Weber E (2014) How warm days increase belief in global warming. Nat. Clim. Chang. 4(2):143-147 